\title{
Neonatal Surgery Case Fatality and Associated Factors in a Cuban Pediatric Hospital, 2005- 2015
}

\author{
Regla C. Broche-Candó MD MS, Oramis Sosa-Palacios MD MS, Eduardo Morales-Mesa MD MS, Mirtha Pla-Ampudia MD, \\ Oneida Reyes-Romero MD MS, María Antonia Pérez-Moré MD
}

\begin{abstract}
INTRODUCTION Newborns in need of surgery are a challenge to manage and require highly specialized centers with multidisciplinary surgical teams. Since the 1980s, neonatal surgical survival has increased by up to $70 \%$ in some countries, mainly due to advances in neonatal intensive care, anesthesia and surgical technique.
\end{abstract}

OBJECTIVE Describe surgical case fatality and survival in a neonatal reference hospital in Cuba, estimate risk of death, and identify potential risk predictors among neonatal characteristics.

METHODS A retrospective cohort study was conducted based on hospital administrative data and clinical records for a series of surgical cases in the neonatal intensive care unit of Havana's William Soler University Children's Hospital from January 2005 to December 2015. All neonates who underwent surgery during the study period were included. The dependent variable was discharge status (alive, deceased); independent variables were: sex, age (in days) at time of surgery, gestational age, birth weight, indication for surgery, surgical order (first, repeat), and presence of sepsis or other postoperative complications. The study used contingency tables to analyze associations between neonatal characteristics and

\section{INTRODUCTION}

Since the second half of the 20th century, there have been reports of improvements of up to $70 \%$ in survival rates following neonatal surgery, mainly due to advances in neonatal intensive care, anesthesia and surgical technique.[1-3]

Neonatal surgery is most commonly performed to correct congenital malformations or birth defects,[2] which are structural anomalies present at birth, whether caused by genetics, pre- or postconception exposure to environmental factors, or some combination of the two.[4] Birth defects requiring neonatal surgery include malformations of several systems: circulatory (especially the cardiac septa, major arteries and veins, and the ventricles and their connections), digestive (such as absence, atresia and stenosis of the esophagus or intestines), nervous, musculoskeletal, respiratory and urinary; as well as diaphragmatic hernia and abdominal wall defects.[4-11]

The complexity of neonatal surgery calls for knowledge and skills that go beyond surgical technique.[12,13] Fluid-electrolyte balance, respiratory and hemodynamic status, and infection risk must be assessed constantly and dynamically to avoid destabilization.

Overall incidence of birth defects varies widely from country to country. The Latin American Collaborative Study on Congenital Malformations (ECLAMC) found an overall prevalence of birth defects in nine participating countries (Argentina, Bolivia, Brazil, Colombia, Chile, Ecuador, Paraguay, Uruguay and Venezuela) discharge status. A classification tree was used to obtain simple estimates of surgical risk.

RESULTS Survival was $91.3 \%$ (675/739) among 739 neonates who underwent surgery. The majority were male $(58.7 \%, 434 / 739)$, full term $(84.2 \%, 622 / 739)$, and of normal birth weight $(80.6 \%, 596 / 739)$. Most surgeries were performed in the first 10 days of life. Digestive system anomalies constituted the most common surgical indication $(57.6 \%$, 426/739); among these anorectal malformations (26.8\%, 114/426) and esophageal atresia $(17.4 \%, 74 / 426)$ predominated. Survival rates were lower for digestive perforation $(57.7 \%, 15 / 26)$, gastroschisis $(57.1 \%, 4 / 7)$ and intestinal atresia $(73 \%, 27 / 37)$. Neonates in the youngest and oldest age groups at time of surgery faced highest risk of death, especially those in the older group. Term infants with normal birth weight operated on for the first time had survival rates $>95 \%$.

CONCLUSIONS Survival was high and low birth weight conferred the worst prognosis. Infants with normal birth weight operated on for the first time had the greatest probability of survival.

KEYWORDS Neonatal surgery; intensive care, neonatal; congenital disorders; birth defects, congenital abnormalities, surgery; surgery, mortality; case fatality; Cuba

of $2.7 \%$, ranging from a low of $1.4 \%$ in Ecuador to a high of $4.2 \%$ in Brazil.[14,15] Large population studies have estimated prevalence of major congenital malformations at $2 \%-3 \%$ of all live births in developed countries, and up to $7 \%$ in developing countries.[5,14] Globally, approximately $1.6 \%$ of neonates have congenital malformations that can be lethal or disabling if not diagnosed promptly and treated appropriately.[11,16-18]

In Cuba, the most common birth defects contributing to infant mortality are congenital cardiopathies, followed by digestive system anomalies, diaphragmatic hernias, chromosomal disorders, and malformations of the central nervous system.[19] About half of the malformations are in the cardiovascular apparatus and of these, about $25 \%$ are severe.[7,8,19] Cuba's success in reducing infant mortality (4.3 per 1000 live births in 2015),[19] is due, among other things, to strategies to reduce morbidity and mortality caused by birth defects.[6] However, birth defects and chromosomal anomalies were still the second leading cause of infant death in Cuba in 2014, with a rate of 0.9 per 1000 live births.[19]

In order to improve population quality of life and reduce infant mortality, in the early 1980s, Cuba's National Health System (SNS) implemented the National Program for Diagnosis, Management and Prevention of Genetic Diseases and Birth Defects, which provides serum alpha-fetoprotein testing, amniocentesis and high resolution ultrasound.[6] When a birth defect is detected prenatally, parents receive genetic counselling on its consequences and prospects, and informed of their options, including pregnancy termination and its risks in the case of potentially lethal or highly disabling anomalies.[6] Early diagnosis, followed by appropriate 
surgical correction, increases these newborns' survival and life expectancy.[20]

Dr Guillermo Hernández Amador, pioneer of neonatal surgery in Cuba, began to perform it in 1966 in Havana's William Soler University Children's Hospital (HPUWS).[21] In 1970, Dr Olimpo Moreno established the HPUWS neonatal intensive care unit (NICU), since then the neonatal surgery reference center for western Cuba (the provinces of Mayabeque, Artemisa, Havana and Pinar del Río, and the Isle of Youth Special Municipality). It provides comprehensive neonatal clinical and surgical services, with the exception of neurosurgery and cardiovascular surgery (such cases are referred to the Juan Manuel Márquez Pediatric Hospital neonatal neurosurgical unit and the William Soler Heart Center, respectively).

There are few published reports on surgical activity in Cuba's neonatal surgical centers, particularly on factors affecting case fatality and survival. This study's main objectives were to describe neonatal surgical case fatality and survival in HPUWS in 2005-2015, estimate risk of death, and identify neonatal characteristics predictive of mortality.

\section{METHODS}

Design and population We used hospital administrative data and clinical records to conduct a retrospective cohort study of case fatality in a series of 739 patients in HPUWS' NICU from January 2005 to December 2015, inclusive.

Analysis The dependent variable was discharge status (alive, deceased). Independent variables were sex (female, male) age (in days) at time of surgery, gestational age (premature $<37$ weeks, full term 37-41 weeks, post-term $\geq 42$ weeks), birth weight (low $<2500$ g, normal $2500-4000 \mathrm{~g}$, high $>4000 \mathrm{~g}$ ), surgical indication, surgical order (first, repeat) and other neonatal characteristics presumably associated with risk of death (sepsis, other complications).

Contingency tables were constructed and analyzed to assess associations between neonatal characteristics and discharge status. A classification tree was used to obtain simple estimates of surgical risk and identify predictive variables.

Ethics Signed informed consent is not required for studies based on administrative data. Data collection and processing incorporated procedures to ensure patient anonymity and confidentiality. The study was approved by the HPUWS Scientific Council and Ethics Committee.

\section{RESULTS}

During the study period, 5836 neonates were admitted to the NICU, of whom 739 underwent surgery (12.7\%). Surgery incidence peaked in 2013 at 18.4 per 100 admissions (94/512). The highest case fatality occurred in 2005 at $18.2 \%$, although rates were generally stable, and lower, over the study period (Table 1). Approximately $57 \%$ of surgeries were performed on boys.

On average, surgery was performed in the first 9.3 days of life (median 3), with 6 patients operated on the day they were born and $64.5 \%(477 / 739)$ in the first 10 days of life. One outlier had surgery on day 80 .

Most neonates were of normal weight (80.6\%, 596/739); the majority were born at full term $(84.2 \%, 622 / 739)$ (Table 2).
Table 1: Neonatal surgical case fatality, HPUWS, 2005-2015

\begin{tabular}{|c|c|c|c|}
\hline Year & Surgeries & & Deaths $n(\%)$ \\
\hline 2005 & & 55 & $10(18.2)$ \\
\hline 2006 & & 62 & $6(9.7)$ \\
\hline 2007 & & 67 & $6(9.0)$ \\
\hline 2008 & & 59 & $9(15.3)$ \\
\hline 2009 & & 67 & $4(6.0)$ \\
\hline 2010 & & 57 & $4(7.0)$ \\
\hline 2011 & & 65 & $4(6.2)$ \\
\hline 2012 & & 91 & $5(5.5)$ \\
\hline 2013 & & 94 & $6(6.4)$ \\
\hline 2014 & & 65 & $3(4.6)$ \\
\hline 2015 & & 57 & 7 (12.3) \\
\hline Total & & 739 & $64(8.7)$ \\
\hline
\end{tabular}

HPUWS: William Soler University Pediatric Hospital

Table 2: Neonatal surgical case fatality* by patient characteristics, HPUWS, 2005-2015

\begin{tabular}{|c|c|c|}
\hline Variable & Cases & Deaths n (\%) \\
\hline $\begin{array}{l}\text { Birth weight } \\
\text { Normal } \\
\text { Low }\end{array}$ & $\begin{array}{l}596 \\
143\end{array}$ & $\begin{array}{r}27(4.5) \\
37(25.9)\end{array}$ \\
\hline $\begin{array}{l}\text { Gestational age } \\
\text { Full term } \\
\text { Preterm }\end{array}$ & $\begin{array}{l}622 \\
117\end{array}$ & $\begin{array}{r}34(5.5) \\
30(25.6)\end{array}$ \\
\hline $\begin{array}{l}\text { Associated morbidity } \\
\text { None } \\
\text { Sepsis } \\
\text { Other complications }\end{array}$ & $\begin{array}{r}543 \\
35 \\
161\end{array}$ & $\begin{array}{r}36(6.6) \\
5(14.3) \\
23(14.3)\end{array}$ \\
\hline $\begin{array}{l}\text { Surgical order } \\
\text { First } \\
\text { Repeat }\end{array}$ & $\begin{array}{r}651 \\
88\end{array}$ & $\begin{array}{r}49(7.5) \\
15(17.0)\end{array}$ \\
\hline $\begin{array}{l}\text { Age at surgery (days) } \\
0-10 \\
11-20 \\
21-30 \\
>30\end{array}$ & $\begin{array}{r}477 \\
124 \\
123 \\
15\end{array}$ & $\begin{array}{r}56(11.7) \\
1(0.8) \\
4(3.2) \\
3(20.0)\end{array}$ \\
\hline
\end{tabular}

${ }^{*} 8.7 \%$ overall, $64 / 739$

HPUWS: William Soler University Pediatric Hospital

Overall survival was $91.3 \%(675 / 739)$. Operations to correct digestive malformations were the most common $(57.6 \%, 426 / 739)$. Anorectal malformations and esophageal atresias were the most common digestive malformations (Table 3). Approximately $46 \%$ (34/74) of neonates with esophageal atresias had other major associated malformations, including complex cardiopathies (5/34), anorectal malformations (5/34), and skeletal and renal malformations (2/34). VATER syndrome (vertebrae, anus, trachea, esophagus, and renal abnormalities) was present in $44.1 \%(15 / 34)$ of patients with esophageal atresia. One patient had annular pancreas and gastric perforation, two had diaphragmatic hernias and another two had multiple malformations.

The highest case fatality rates were among neonates with digestive malformations $(71.9 \%, 46 / 64)$ : digestive perforation $(42.3 \%)$, intestinal atresia $(27 \%)$, and esophageal atresia $(18.9 \%)$. Case fatality for neonates with abdominal wall defects was $42.9 \%(3 / 7)$ for gastroschisis and $25 \%(3 / 12)$ for omphalocele (Table 3).

Case fatality distribution for age at time of surgery was J-shaped, with rates of $11.6 \%$ in the first 10 days and $20 \%$ after 30 days, but 
$<5 \%$ at $11-30$ days. Figure 1 illustrates risk of death according to neonatal characteristics, notably:

0.087 overall;

0.045 for newborns with normal birth weight;

0.259 (almost triple overall risk) for newborns with low birth weight; 0.038 for newborns with normal birth weight and first surgery, but 0.104 for repeat surgery;

0.005 for newborns with normal birth weight and first surgery at age $>10$ days; and

0.059 for newborns with normal birth weight and first surgery at age $0-10$ days.

Prematurity, low birth weight, more than one surgery, and surgical complications all markedly increased risk of death.

Sepsis was the most common surgical complication $(4.7 \%$, $35 / 739)$, most often caused by coagulase-negative staphylococci $(40 \%, 14 / 35)$ and Staphylococcus aureus $(25.7 \%, 9 / 35)$. Among noninfectious complications, the most common were wound dehiscence $(4.7 \%, 35 / 739)$, obstructed airways $(4.2 \%, 31 / 739)$ and clotting disorders $(2.8 \%, 21 / 739)$.

A simple algorithm based on classification trees determined that low birth weight and repeat surgery were the two conditions that

Table 3: Neonatal surgical case fatality and survival by surgical indication, HPUWS, 2005-2015

\begin{tabular}{|c|c|c|c|c|c|c|}
\hline \multirow{3}{*}{ Indication } & \multicolumn{6}{|c|}{ Discharge status } \\
\hline & \multicolumn{2}{|c|}{ Deaths } & \multicolumn{2}{|c|}{ Survivals } & \multicolumn{2}{|c|}{ Total } \\
\hline & $n$ & $\%$ & $n$ & $\%$ & $n$ & $\%{ }^{\mathrm{a}}$ \\
\hline \multicolumn{7}{|l|}{ Digestive malformations } \\
\hline Anorectal malformation & 2 & 1.8 & 112 & 98.2 & 114 & 26.8 \\
\hline Esophageal atresia & 14 & 18.9 & 60 & 81.1 & 74 & 17.4 \\
\hline Hypertrophic pyloric stenosis & 1 & 1.9 & 53 & 98.1 & 54 & 12.7 \\
\hline Intestinal aganglionosis & 1 & 1.9 & 52 & 98.1 & 53 & 12.4 \\
\hline Intestinal atresia & 10 & 27.0 & 27 & 73.0 & 37 & 8.7 \\
\hline Digestive perforation & 11 & 42.3 & 15 & 57.7 & 26 & 6.1 \\
\hline Intestinal malrotation & 1 & 4.2 & 23 & 95.8 & 24 & 5.6 \\
\hline Other ${ }^{b}$ & 6 & 13.6 & 38 & 86.4 & 44 & 10.3 \\
\hline Subtotal & 46 & 10.8 & 380 & 89.2 & 426 & $100.0^{c}$ \\
\hline \multicolumn{7}{|l|}{ Nondigestive malformations } \\
\hline Inguinal hernia & 0 & 0.0 & 85 & 100.0 & 85 & $27.2^{\mathrm{d}}$ \\
\hline Tumors & 1 & 2.8 & 35 & 97.2 & 36 & 11.5 \\
\hline Ovarian cyst & 0 & 0.0 & 32 & 100.0 & 32 & 10.2 \\
\hline Diaphragmatic hernia & 5 & 20.0 & 20 & 80.0 & 25 & 8.0 \\
\hline Omphalocele & 3 & 25.0 & 9 & 75.0 & 12 & 3.8 \\
\hline Gastroschisis & 3 & 42.9 & 4 & 57.1 & 7 & 2.2 \\
\hline Othere & 6 & 5.0 & 110 & 95.0 & 116 & 37.1 \\
\hline Subtotal & 18 & 5.8 & 295 & 94.2 & 313 & $100.0^{f}$ \\
\hline Total & 64 & 8.7 & 675 & 91.3 & 739 & 100.0 \\
\hline
\end{tabular}

${ }^{a}$ of total digestive malformations $(n=426)$

bintestinal stenosis (13), bile duct malformations (12), annular pancreas (6) gastrostomy (5), meconium ileus (4), enteric cyst (1), necrotizing enterocolitis (1), gastroesophageal reflux (1), intestinal volvulus (1)

$557.6 \%$ of total $(426 / 739)$

dof total nondigestive malformations $(n=313)$

ebiopsies (20), urological malformations (15), testicular torsion (14),

ophthalmologic malformations (13), septic arthritis (7), deep abscesses (6) amputation of limbs (5), tracheotomy (5), maxillofacial surgery (4), umbilical defects (4), blockage of choanae (4), diaphragmatic defects (4), hematomas (4), lobar emphysema (2), hydronephrosis (2), nesidioblastosis (2), hydrocele (1),

laryngeal stridor (1), tracheobronchial malformation (1), empyema (1), dislocated shoulder (1)

$42.4 \%$ of total $(313 / 739)$

HPUWS: William Soler University Pediatric Hospital best predicted death. Other variables such as prematurity or complications that were important in univariate analysis but did not add appreciably to predictive capacity did not emerge as predictors in the algorithm.

Figure 1: Classification tree predicting discharge status based on low birth weight, surgical order and age at surgery*

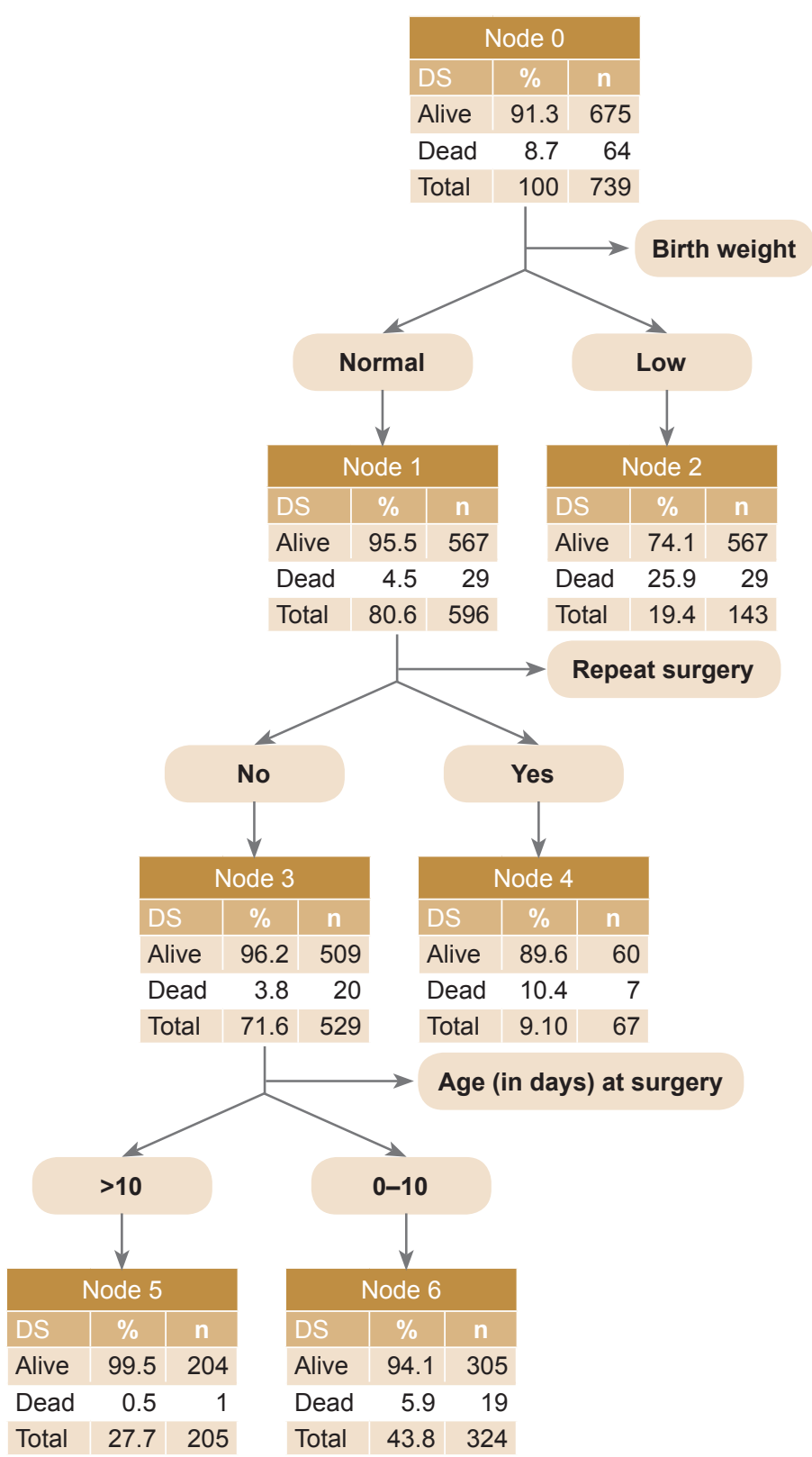

*Prematurity and complications were entered in the initial model but did not emerge in the prediction algorithm.

DS: discharge status

\section{DISCUSSION}

Neonates undergoing surgery are still adapting to extrauterine life; their fragile homeostasis is placed in double jeopardy by their complex medical conditions and the stresses of surgery and anesthesia.[22] Such surgery constitutes a global challenge, although associated mortality is low in developed countries, which generally enjoy better organization of NICUs, greater resources 
and better infrastructure, highly qualified personnel, and more advanced maternal and fetal medicine and reproductive genetics.[23]

Transportation is a fundamental component in care of neonates with birth defects requiring specialized treatment, since prompt surgery can minimize complications.[24-27] In Cuba, transferring neonates between settings is considered a risk factor. When unavoidable, it is done as safely and efficiently as possible, in a specially equipped ambulance staffed with a neonatologist and specialized nurse.[26]

Most of the neonates we studied were operated on in the first 10 days of life, which reflects Cuba's health service coverage and accessibility and also helps explain the high survival rate. Optimal surgical timing is possible when there is appropriate clinical assessment and good patient status. Fewer and fewer neonatal surgical indications require immediate treatment.[28,29] Our study found the lowest case fatality among those operated on days 11-30. Higher case fatality at earlier ages could partly reflect more serious conditions becoming apparent earlier. The almost tenfold increase in risk for normal weight infants operated on for the first time at $<10$ days compared to their older peers supports this possibility.

The preponderance of male sex among neonatal surgical patients is consistent with reported higher rates in male infants of birth defects such as intestinal atresias and hypertrophic pyloric stenosis, the latter with neonatal sex ratio of $4: 1 .[22,28-34]$

Other authors have observed neonatal mortality inversely proportional to gestational age,[12,35-37] which is consistent with our finding of fivefold higher risk of death in preterm neonates.[38,39]

The most important established predictor of neonatal mortality and morbidity is birth weight: Low birth weight substantially increases the likelihood of illnesses and complications in children aged less than one year.[32,33,40] This was confirmed in our study, which found low birth weight a powerful risk factor for surgical mortality (the a priori risk of 0.087 almost tripled for newborns with low birth weight and fell to less than half for newborns with normal birth weight undergoing first surgery).

Chances of surviving the first month of life are influenced by various environmental, social and genetic factors.[11] With few exceptions, surgery is an emergency. Optimal surgical timing is determined by the neonatologist and the surgeon, based on the newborn's condition. However, in our experience, if a defect can be corrected in an early neonatal stage, this can be result in faster recovery and better survival rates, especially in the case of digestive malformations. Holguin's regional neonatal surgery center (in eastern Cuba) reports $91.9 \%$ survival after neonatal surgery,[41] findings similar to ours.

The greater frequency of digestive system congenital malformations (especially anorectal malformations and esophageal atresia) in our study is consistent with findings by other authors in Cuba and elsewhere.[28,33,42,43]

Esophageal atresia is a common birth defect globally, occurring in 1 of every 3000 births; $50 \%$ of patients have other associated malformations.[34,44] It is considered a surgical emergency, since it is lethal if not corrected. Contemporary surgical treatment of esophageal atresia permits $>95 \%$ survival.[45] The lower survival rates we observed in our study could be due to accompanying other major malformations, especially complex anorectal, skeletal and renal anomalies, all of which affect clinical outcomes.[46]

Congenital diaphragmatic hernia is one of the biggest remaining challenges in neonatal surgery. Mortality results directly from hypertension at birth combined with pulmonary hypoplasia induced by intestinal herniation during critical stages of pulmonary development.[1] Despite substantial progress in diagnosis and treatment, mortality from this condition is still $30 \%-60 \%,[1,41]$ higher than observed in our study.

Intestinal atresias are the main cause of intestinal occlusion in the neonate; postoperative mortality depends on various factors: anatomical site, associated anomalies, short bowel syndrome, and obstruction from bands or volvulus.[45] Survival rates in our study were comparable to Cuban rates reported elsewhere.[19,46]

Survival of neonates with abdominal wall defects, particularly gastroschisis, would be impossible without major advances in NICUs. $[10,11,41]$ Our $>50 \%$ survival can be considered good, although the small number of cases means results should be interpreted with caution.

During the postoperative period, neonates are vulnerable to various complications, most commonly, infection.[47,48] Infection at the surgical site constitutes the primary cause of infection associated with surgical care (40\% of postsurgical infections),[19] and is the third leading cause of infection associated with medical treatment in children (14\%-16\%).[47-52] Wound sepsis is preventable but, despite advances in surgical technique, continues to be one of the main challenges in treatment of congenital intestinal malformations. In our study, infectious complications were uncommon, even among patients who did not survive.

Complications during surgical recovery prolong neonatal hospital stay and increase surgical costs and risk of death.[9-11] In our series, patients who died had at least one predictor of neonatal death, most commonly low birth weight. Low prematurity rates in the population studied may be considered a successful outcome of Cuba's National Maternal-Child Health Program.[53]

The study's main constraint is that it does not include neonates operated on for congenital cardiopathies or neurological malformations, since these surgeries are not performed at HPUWS. Since these are the most common birth defects requiring neonatal surgery, this hinders comparisons with other studies. Future multicenter studies could provide more information on neonatal mortality from the full range of birth defects.

\section{CONCLUSIONS}

Recent important developments in neonatal surgery in Cuba may explain high neonatal survival rates observed in this study. Our study identified some important predictors and applied a simple practical algorithm to estimate surgical risk based thereon. Our results support the importance of factors such as preterm birth and low birth weight in reducing chances of survival, and these must be addressed to improve prognosis for neonatal surgical patients. $1 /$ - 


\section{REFERENCES}

1. Guelfand M. Patología quirúrgica neonatal: orientación diagnóstica y aportes de la cirugía mínimamente invasiva. Rev Méd Clín Las Condes. 2009;20(6):745-57. Spanish.

2. Bueno J, Peiró JL, Guillén G, Molino JA, Laín A, Royo, et al. Avances en cirugía pediátrica. Rev Española Ped. 2013;69(6):277-85. Spanish.

3. Velázquez Rodríguez $\mathrm{G}$, Trinchet Soler RM, Hidalgo Marrero Y, Figueredo Borrego RJ, Céspedes Gamboa MP. Resultados del Centro Regional de Holguín en la atención, con tratamiento quirúrgico, al recién nacido. Correo Cient Méd Holguín. 2014;18(2):226-37. Spanish.

4. Flores-Nava G, Pérez-Aguilera TV, PérezBernabé MM. Malformaciones congénitas diagnosticadas en un hospital general. Revisión de cuatro años. Acta Pediatra Mex. 2011 MarApr;32(2):101-6. Spanish.

5. Guzmán Sancho I, Ricardo Saint-Félix FM, Muguercia Fornaris A, García Álvarez RI, Vega Sams S. Morbilidad y mortalidad por malformaciones congénitas del sistema nervioso central en menores de un año. MEDISAN. 2014 Dec;18(12):1649-56. Spanish.

6. Marcheco Teruel B. El Programa Nacional de Diagnóstico, Manejo y Prevención de Enfermedades Genéticas y Defectos Congénitos de Cuba: 1981-2009. Rev Cubana Genet Comunit. 2009 May-Dec;3(2-3):167-84. Spanish.

7. Prsa M, Saroli T, Correa JA, Asgharian M, Mackie AS, Dancea AB. Birth prevalence of congenital heart disease. Epidemiology. 2009 May;20(3):466-8

8. Yun SW. Congenital heart disease in the newborn requiring early intervention. Korean $\mathrm{J} \mathrm{Pe}$ diatrics. 2011 May;54(5):183-91.

9. Pierro A. Recent advances in neonatal surgery. Semin Neonatol. 2003 Jun;8(3):195-6.

10. Rowe MI, Rowe SA. The last fifty years of neonatal surgical management. Am J Surg. 2000 Nov;180(5):345-52.

11. Steven Ringer A. Urgencias quirúrgicas en el recién nacido. In: Cloherty JP, Stark AR, editors. Manual de cuidados neonatales. 3rd ed. BarceIona: Editorial Masson SA; 1999. p. 691-708. Spanish.

12. García HJ, Rodríguez-Medina X, Franco-Gutiérrez M, Miranda-Novales G, Villegas-Silva R. Factores de riesgo asociados a infección del sitio quirúrgico en recién nacidos en UCIN. Rev Invest Clín. 2005 May-Jun;57(3):425-33. Spanish.

13. Sola A. Entendiendo las necesidades de un recién nacido que requiere cirugía. In: Cuidados neonatales. Descubriendo la vida de un recién nacido enfermo. Buenos Aires: Edimed; 2011. p. 1310-2. Spanish.

14. World Health Organization [Internet]. Geneva: World Health Organization; c2017. Nicaragua. Boletín informativo. Malformaciones congénitas; 2015 Jun [cited 2016 Apr 21]. Available from: http://www.paho.org/nic/ index.php?option=com_docman\&task=doc download\&gid=711\&ltemid=235. Spanish.

15. Nazer HJ, Cifuentes OL. Malformaciones congénitas en Chile y Latino América: Una visión epidemiológica del ECLAMC del período 1995-2008. Rev Med Chil. 2011 Jan;139(1):72-8. Spanish.

16. Murray CJ, Vos T, Lozano R, Naghavi M, Flaxman AD, Michaud C, et al. Disability-adjusted life years (DALYs) for 291 diseases and injuries in 21 regions, 1990-2010: a systematic analysis for the Global Burden of Disease Study 2010. Lancet. 2012 Dec 15;380(9859):2197-223.

17. Hagander L, Kabir M, Chowdhury Z, Gunnarsdóttir A, Habib G, Banu T. Major neonatal surgery under local anesthesia: a cohort study from Bangladesh. World J Surg. 2015 Apr;39(4):953-60.
18. Valdés Armenteros R, Ruiz Tellechea $Y$, Morilla Guzmán A, Domínguez Dieppa F, Montes López E, Camejo Plasencia A, et al. Cirugía en el recién nacido. In: Bello Álvarez D, editor. Neonatología: diagnóstico y tratamiento. Havana: Editorial Ciencias Médicas; 2012. p. 344. Spanish.

19. National Health Statistics and Medical Records Division (CU). Anuario Estadístico de Salud 2015. Havana: Ministry of Public Health (CU); 2016. 208 p. Spanish.

20. Casanova Arzola R. Factores de avance en el desarrollo de la Pediatría en Cuba. Rev Cubana Ped. 1988;60(6):903-7. Spanish.

21. Rojas Aguilera A. Trinchet, entre los tres grandes de la ciencia holguinera. Ahora.cu [Internet]. 2014 Mar 17 [cited 2016 Apr 21]; [about 2 screens]. Available from: http://www.ahora.cu/ secciones/holguin/12232-trinchet-entre-los-tres -grandes-de-la-ciencia-holguinera. Spanish.

22. Kuebler JF, Ure BM. Minimally invasive surgery in the neonate. Semin Fetal Neonatal Med. 2011 Jun;16(3):151-6.

23. Osifo DO, Ovueni ME. The prevalence, patterns and causes of death of surgical neonates at two African referral pediatrics surgical. Ann Pediatric Surgery. 2009;5(3):194-9.

24. Piña Yáñez Y. Manejo del recién nacido quirúrgico. Guías de diagnóstico y tratamiento del Servicio de Neonatología. Hospital San Juan de Dios [Internet]. Chile: Scribd; 2006 [cited 2016 Apr 21]. Available from: http://www.scribd.com/ doc/131989615/Guias-de-diagnostico-y-trata miento-del-Servicio-de-Neonatologia-Hospital -San-Juan-de-Dios. Spanish.

25. Thió M, Esqué M, Alarcon M, Esque MT. Transporte Neonatal. In: Moro Serrano M, Vento Torres M, editores. De guardia en Neonatología. 2nd ed. Barcelona: Ergon. 2008. p.157-65. Spanish.

26. Camué Luis R, Trinchet Soler RM, Hidalgo Marrero Y, Velázquez Rodríguez G, Ellis-Davy JJ. Evaluación de los resultados del traslado del recién nacido con tratamiento quirúrgico. Correo Cientif Méd Holguín. 2015 Jan-Mar;19(1):51-62. Spanish.

27. Ratnavel N. Evaluating and improving neonatal transport services. Early Hum Dev [Internet]. 2013 Nov [cited 2016 Apr 21];89(11):851-3. Available from: https://linkinghub.elsevier.com/ retrieve/pii/S0378-3782(13)00224-7

28. Guelfand CHM, Santos MM, Olivos PM, García Larraín I. Cirugía mínimamente invasiva en recién nacidos de $<2.500 \mathrm{~g}$. Rev Chilena Pediatr. 2014 Feb;85(1):64-7. Spanish.

29. Díaz Díaz J, Ledesma A, Rojas Rodríguez Y. Cirugía neonatal. Hospital Pediátrico. Cienfuegos 2000-2003. MEDISUR [Internet]. 2005 [cited 2016 Apr 26];3(1):19-23. Available from: http://medisur.sld.cu/index.php/medisur/article/ view/82. Spanish

30. Holcomb GW III, Murphy JP, editors. Ashcrfts Pediatric Surgery. 5th ed. Philadelphia: SaundersElsevier; 2010.

31. Taylor ND, Cass DT, Holland AJ. Infantile hypertrophic pyloric stenosis: has anything changed? J Paediatr Child Health. 2013 Jan;49(1):33-7.

32. Mejía SH. Factores de riesgo para muerte neonatal. Revisión sistemática de la literatura. Rev Soc Bol Ped. 2000;39:104-17. Spanish.

33. Catré D, Lopes MF, Madrigal A, Oliveiros B, Viana JS, Cabrita AS. Early mortality after neonatal surgery: analysis of risk factors in an optimized health care system for the surgical newborn. Rev Brasileira Epidemiol. 2013 Dec;16(4):943-52.

34. Jakubson L, Paz F, Zavala A, Harris PR, Bertrand P. Atresia esofágica y fístula traqueoesofágica. Evolución y complicaciones postquirúrgicas. Rev Chil Pediatr. 2010;81(4):339-46. Spanish.
35. Solís F, Mardones G, Castillo B, Romero Ml Mortalidad por inmadurez e hipoxia como causas centinelas de atención obstétrica y neonatal. Rev Chil Pediatr. 1993 Nov-Dec;64(6):384-91. Spanish.

36. Chan LC, Cheung HM, Poon TC, Ma TP, Lam HS, Ng PC. End-of-life decision-making for newborns: a 12-year experience in Hong Kong. Arch Dis Child Fetal Neonatal Ed. 2016 Jan;101(1):F37-42.

37. Baird R, Gholoum S, Laberge JM, Puligandla P. Prematurity, not age at operation or incarceration, impacts complication rates of inguinal hernia repair. J Ped Surgery. 2011 May;46(5):908-11.

38. Grandi C, González A, Zubizarreta J; Red Neonatal NEOCOSUR. Factores perinatales asociados a la mortalidad neonatal en recién nacidos de muy bajo peso: estudio multicéntrico. Arch Argent Pediatr. 2016 Oct 1;114(5):426-33. Spanish, English.

39. Fernández R, D’Apremont I, Domínguez A, Tapia JL; Red Neonatal NEOCOSUR. Supervivencia y morbilidad en recién nacidos de muy bajo peso al nacer en una Red Neonatal sudamericana. Arch Argent Pediatr. 2014 Oct;112(5):405-12. Spanish, English.

40. Salazar-Hernández AC, Martínez-Torres J, Hernández-Cruz SC. Peso bajo al nacer en neonatos enfermos. Factores asociados. Rev Mexicana Ped. 2001 Sept-Oct;68(5):185-8. Spanish.

41. Trinchet Soler RM. Resultados en la Cirugía Neonatal. Controversias, temores y análisis científico. Rev Cubana Genet Comunit. 2012;6(1):57. Spanish.

42. Ekenze SO, Ajuzieogu OV, Nwomeh BC. Neonatal surgery in Africa: a systematic review and meta-analysis of challenges of management and outcome. Lancet. 2015 Apr 27;385 Suppl 2:S35.

43. Ameh EA, Seyi-Olajide JO, Sholadoye TT Neonatal surgical care: a review of the burden, progress and challenges in sub-Saharan Africa. Paediatr Int Child Health. 2015 Aug;35(3):243-51.

44. Huskisson LJ, Kirby C. Neonatal surgical problems of the chest. Current Paediatrics. 2002 Feb;12(1):36-42.

45. Gutiérrez-Carrillo MP, Zertuche-Coindreau JM Santana-Cárdenas LC, Esparza-Ponce C, Sánchez-Rodríguez JB, Barrera-de León JC. Descripción de la morbilidad y mortalidad por atresia intestinal en el periodo. Cir Cir. 2013;81:490-5. Spanish.

46. Puente Fonseca CJ. Atresia intestinal yeyuno ileal. MEDISUR. 2005;3(5):13-8. Spanish

47. Pickering LK, Baker CJ, Long S, McMillan JA Antimicrobial prophylaxis in pediatric surgical patients. In: Red Book: Report of the Committee on Infectious Diseases. 27th ed. Illinois: American Academy of Pediatrics; 2006. p. 811.

48. Vialat Soto V, Marchena Béquer JJ, Hernández Alfonso $\mathrm{H}$, de la Rosa Rodríguez R. Infección de los sitios quirúrgicos: estudio de 1 año. Rev Cubana Ped [Internet]. 2008 Jam-Mar [cited 2016 Apr 28];80(1). Available from: http://scielo .sld.cu/scielo.php?script=sci_arttext\&pid=S0034 $-75312008000100004 \&$ Ing=es. Spanish.

49. Alemán-Espinoza W, Miño-León G. Infección en cirugía. Infección del sitio quirúrgico y profilaxis antimicrobiana preoperatoria. Antecedentes. In: Sánchez Sabando J, editor. Libro texto de cirugía [Internet].Guayaquil: Medicosecuador.com; 2002 [cited 2016 Apr 9]. Available from: http://www .medicosecuador.com/librosecng/articuloss/3/ infeccion_en_cirugia.htm. Spanish.

50. López Tagle D, Ramis Andalia R, Bayarre Vea H, Guanche Garcell H. Incidencia de infección en 
heridas quirúrgicas en hospital de Ciudad de La Habana: Período enero-junio, 2004. Rev Cubana Hig Epidemiol [Internet]. 2007 Sep-Dec [cited 2016 Apr 26];45(3). Available from: http://scielo sld.cu/scielo.php?script=sci_arttext\&pid=S1561 $-30032007000300003 \&$ Ing=es. Spanish.

51. Ramis Andalia $R$, Bayarre Vea $H$, Barrios Díaz M, López Tagle D, Bobadilla González C, Chinea Delgado M. Incidencia de infección en heridas quirúrgicas en servicios de cirugía general seleccionados. Rev Cubana Salud Pública [Internet]. 2007 [cited 2016 May 9];33(1). Available from: http://scielo.sld cu/scielo.php?script=sci arttext $\&$ pid=S0864 $-34662007000100005 \&$ Ing=es. Spanish.

52. Bracho-Blanchet E, González-Chávez A, DávilaPérez $R$, Zalles-Vidal $C$, Fernández-Portilla E, Nieto-Zermeño J. Factores pronóstico para mortalidad en neonatos con atresia intestinal yeyuno-ileal. Cir Cir. 2012;80(4):345-51.

53. Robaina Castellanos GR, Riesgo Rodríguez SC. Propuesta de programa de seguimiento de recién nacidos de alto riesgo en Cuba. Rev Méd Electrón [Internet]. 2011 Sep-Oct [cited 2016 Jun3];33(5):645-55. Available from: http:// scielo.sld.cu/scielo.php?script=sci arttext\&pid =S1684-18242011000500012. Spanish.

\section{THE AUTHORS}

Regla C. Broche-Candó (Corresponding author: reglabroche@infomed.sld.cu), physician with dual specialties in family medicine and neonatology, with a master's degree in infectious diseases. Associate professor and adjunct researcher, Medical University in Havana, and staff neonatologist at William Soler University Children's Hospital (HPUWS), Havana, Cuba.

Oramis Sosa-Palacios, physician specializing in biostatistics with a master's degree in health informatics. Associate professor and adjunct researcher, HPUWS, Havana, Cuba.

Eduardo Morales-Mesa, neonatologist with a master's degree in comprehensive child health. Assistant professor and associate researcher, HPUWS, Havana, Cuba.

Mirtha Pla-Ampudia, physician with dual specialties in pediatrics and neonatology HPUWS, Havana, Cuba.
Oneida Reyes-Romero, physician with dual specialties in pediatrics and neonatology and a master's degree in comprehensive child health, HPUWS, Havana, Cuba.

María Antonia Pérez-Moré, physician with dual specialties in pediatrics and neonatology, HPUWS, Havana, Cuba.

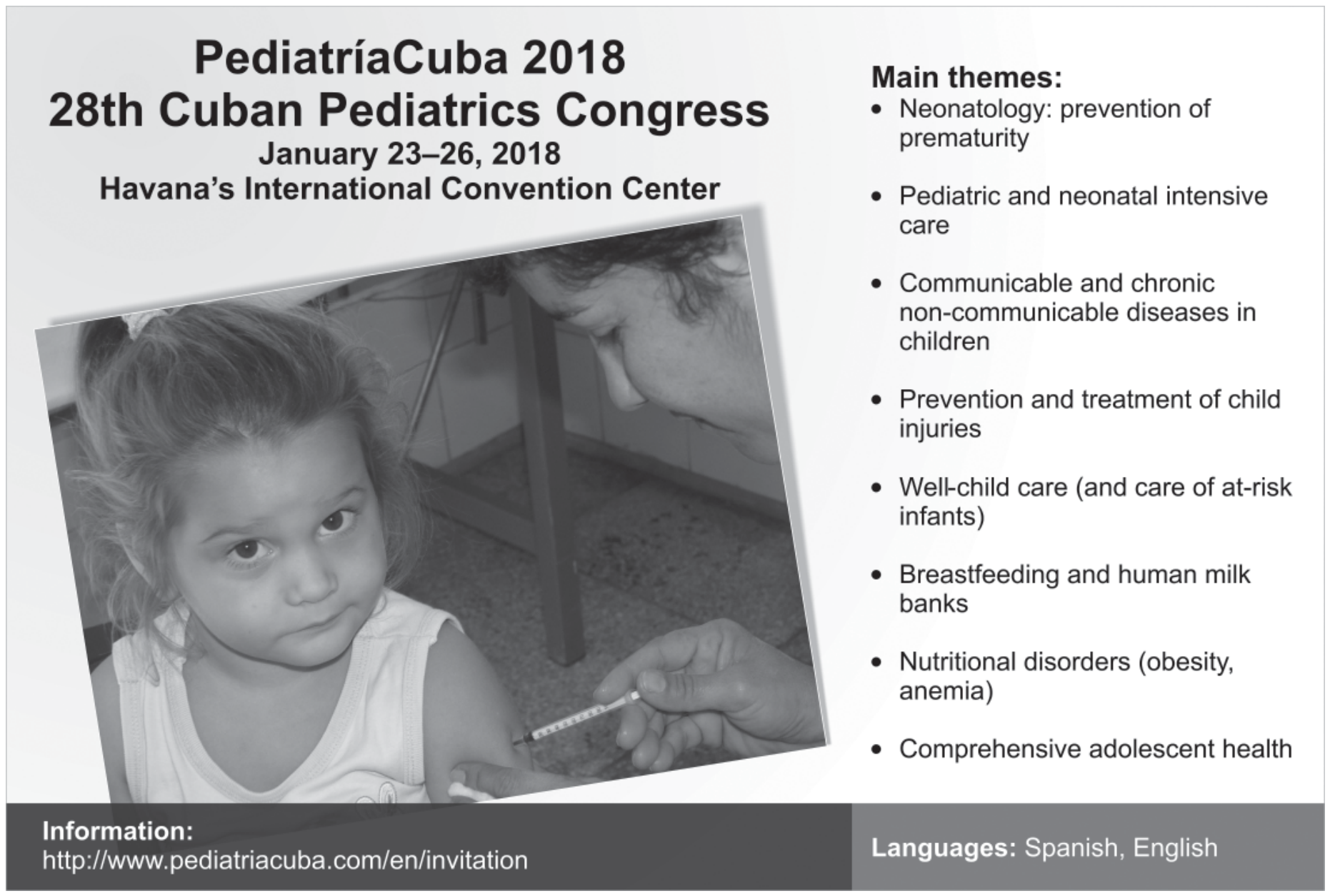

